\title{
DETERMINANTS OF YOUTH EMIGRATION: A CASE STUDY \\ OF KARACHI \\ (An Overview of emigration from 2010 to 2016)
}

\author{
Ammad Zafar*
}

\begin{abstract}
In the last six years, more than 3.7 million people have migrated from Pakistan to seek employment, mostly in the Middle East. Approximately, 1 million people migrated from Pakistan in 2015 in contrast to 0.75 million in 2014, an increase of about 20.84\%. People from all the cities of Pakistan are migrating, especially from Karachi, which is the seventh most populous city of the world and largest in Pakistan. More than $30 \%$ of Karachi's population is youth (ages 15 -29) with $54.9 \%$ male and $45.1 \%$ female. This study finds that $48.7 \%$ of the youth in Karachi want to leave Pakistan for various reasons, including unemployment, insecurity, economic problems, lack of social support, lack of career opportunities. This high rate of outward migration from Pakistan is creating brain drain conditions, especially in the health and education sectors, where there is a shortage of skilled workforce. This paper explores and analyzes factors that are contributing to youth emigration from Pakistan's largest city, Karachi.
\end{abstract}

Keywords: Youth emigration, unemployment, insecurity, economic problems

\section{Introduction}

Approximately 3.7 million people have migrated from Pakistan since $2010^{1}$. People are migrating from Pakistan not just to seek employment but other factors also. The rate of emigration from Pakistan has increased $20.84 \%$ in 2014 and $25.80 \%$ in $2015^{2}$. This increase in out migration brings both unique opportunities and challenges ${ }^{3}$. According to the New York Times, Pakistan currently has the largest proportion of youth in its population, which is greater than ever before. About $64 \%$ of the Pakistani population is less than 30 years, whereas $31 \%$ of the population falls into the age bracket of $15-29$ years ${ }^{4}$. Addressing the problems of youth is needed to orient them better to potential opportunities and to prevent disillusionment with government policies and the

\footnotetext{
This work is Licensed under a Creative Commons Attribution-Non-Commercial 4.0 International License. (c) () (8)

* Ammad Zafar, Visiting Faculty, Benazir Bhutto Shaheed University, Lyari, Karachi

${ }^{1}$ Bureau of Emigration \& Overseas Employment Government of Pakistan. Occupational Wise 2016. http://www.beoe.gov.pk/files/statistics/occupational-wise-2016.pdf.

${ }^{2}$ Ibid.

${ }^{3}$ Youth Employment and Social Cohesion. January 2015.

http://www.pk.undp.org/content/pakistan/en/home/operations/projects/crisis_prevention_and_recovery/youthemployment-and-social-cohesion.html.

${ }^{4}$ UNDP. Jawan Pakistan Youth to Youth Conversion Guidelines. 2015. http://nhdr.undp.org.pk/wpcontent/uploads/2015/05/Raza-Kar-Youth-to-Youth-Conversation-Guidelines.pdf.
} 
democratic process ${ }^{5}$. Youths in Pakistan are emigrating because of a lack of education facilities and employment opportunities, security issues, economic and social opportunities; about $4 \%$ of Pakistani population or approximately 7 million, currently lives abroad ${ }^{6}$, about $48 \%$ of Pakistani emigrants live in the Middle East, $28 \%$ in Europe, $19 \%$ in the United States and 5\% elsewhere. According to a Gallup survey, two thirds of the population of Pakistan wish to leave. The migration rate of highly skilled people increased 60\% from 1992 to 2000. A survey similar to the Gallup one was conducted in 1984 , which showed only $17 \%^{7}$ wanted to leave. The increase in the rate of emigration is constraining the availability of skilled labor which, in turn, is causing a brain drain (unavailability of professionals) in Pakistan. This situation is contributing to a lower level of economic growth and productivity ${ }^{8}$. While social and economic conditions can improve a country or region's work force through migration, the country of origin often experiences a net loss of highly skilled professionals ${ }^{9}$.

This study is part of a research project "Managing Mega Cities", which was supported by the US State Department through the University Partnership Program between George Mason University and the University of Karachi. A survey of 1991 households in Karachi were conducted through a closed-ended questionnaire during 2015 - 2016. In total 11,127 people were interviewed of which nearly $30 \%$ of the respondents were youth. A two-stage stratified sampling method was used to select households ${ }^{10}$.

According to the Karachi Megacity Survey more than 40 percent of the city's youth want to leave Karachi. Insecurity, unemployment, economic problems, lack of opportunities, self-employment lack of social support, mother tongue Urdu, and secondary \& higher education are the main significant factors that are motivating the desire to emigrate. Karachi is receiving less brain skilled people from in migration than those who emigrate. This situation is causing a scarcity of professional and skilled labour in Karachi especially in the health and education sectors. The Government needs to establish vocational training and skill enhancement for immigrants as one way to reduce the continued shortage of skilled labour. The national government in collaboration with Karachi officials should also design and implement a strategy to cope with the causes of the brain drain and to motivate professionals to remain in Karachi by providing better opportunities.

\footnotetext{
${ }^{5}$ New York, Times. Survey of Pakistan's Young Predicts 'Disaster' if Their Needs Aren't Addressed. November 22, 2009. http://www.nytimes.com/2009/11/22/world/asia/22pstan.html.

${ }^{6}$ S.A.R., Hamdani, Bureau of emigration and overseas employment: Performance and evaluation. Bureau of Emigration and overseas Employment, 2006.

${ }^{7}$ Syed, Talal. it's Time to Stop the Brain Drain from Pakistan. September 4, 2015.

https://propakistani.pk/2015/09/04/its-time-to-stop-the-brain-drain-from-pakistan.

${ }^{8}$ UN Administrator. The impact of Youth Migration. December 30, 2013.

http://www.unworldyouthreport.org/index.php?option=com_k2\&view=item\&layout=item\&id=85\&Itemid=22 6.

${ }^{9}$ United Nations. World Youth Report. New York: United Nations, 2013.

${ }^{10}$ Managing Mega City Project Survey 2015
} 


\section{Research Question}

What are the factors that are motivating youth to emigrate from Karachi?

\section{Research Objective}

The objective of this research is to identify those factors that are triggering Karachi youth emigration. This is important for economic development and growth because Karachi and Pakistan are experiencing large-scale emigration of youth thus reducing the skill base of labor available to the region.

\section{Research Hypotheses}

This is exploratory research based on findings through data collected in Megacity Survey. The following hypotheses will be tested using the survey data.

$\mathbf{H}_{1}$ : As insecurity increases so does youth emigration

$\mathbf{H}_{2}$ : As the percent of the youth population receiving middle \& primary education increases so does the percent of youth that emigrates.

H3: As the percent of the youth population receiving secondary \& higher education increases so does the percent of youth that emigrates.

$\mathbf{H}_{4}$ : As unemployment increases so does youth emigration

Hs: As self-employed youth increases so does youth emigration

H6: As lack of opportunities increases so does youth emigration

$\mathbf{H}_{7}$ : As lack of social support decreases youth emigration increases

H8: As economic problems increase youth emigration increases

H9: As the proportion of Urdu speaking people increases youth emigration also

\section{Literature Review}

\section{Case Study of Karachi}

Karachi is the seventh most populated city in the world after Yokohama, Jakarta, Delhi Seoul, Manila, Mumbai, Shanghai, New York and Sao Paulo(See Figure 1). 


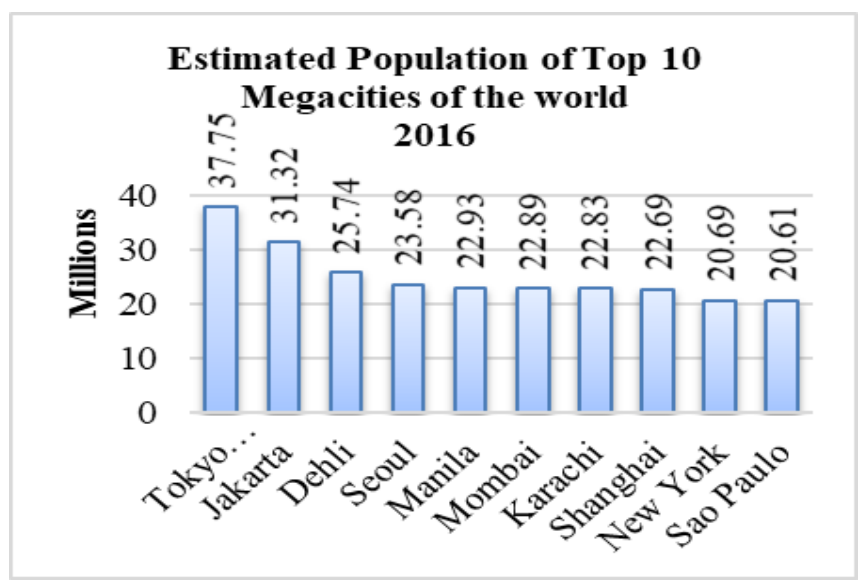

Figure 1

Currently, Karachi's population is 22.8 million $^{11}$ (see Figure 2) and is expected to reach 27.5 million by 2020 , with a growth rate of $3.5 \%$ per annum $^{12}$ and 32 million by $2025^{13}$, assuming an annual growth rate of $3.5 \%{ }^{14}$.

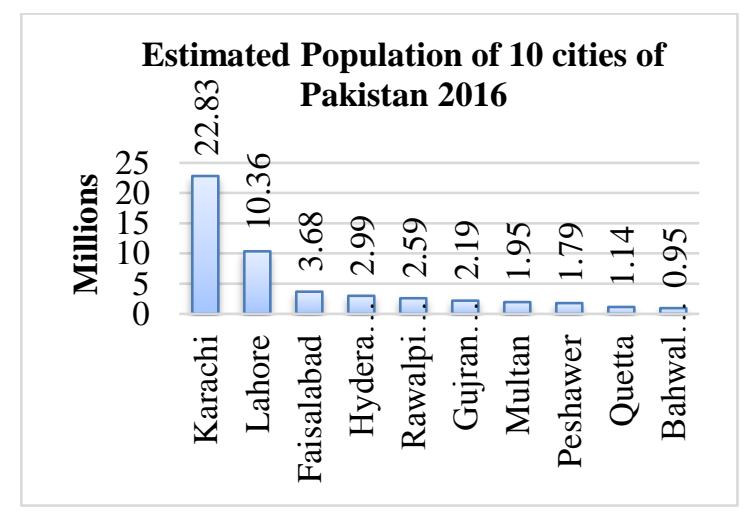

Figure 2

According to the Karachi Mega City Survey 2015, the age of about $30 \%$ of the city's population is below 15 years, $30.1 \%$ population of the city is youth and $39.8 \%$ is 30 years old and above (See Figure 3).

\footnotetext{
${ }^{11}$ Demographia. Dermographia World Urban Areas 12th Annual Edition. April 2016. http://www.demographia.com/db-worldua.pdf.

12 Master Plan group of Offices City District Government Karachi in Association with M/s Engineering consultant (Pvt.) Ltd. Karachi Strategic Development Plan 2020. Karachi: Master Plan group of Offices City District Government Karachi, 2007.

${ }^{13}$ Aziz Ullah, Sharif, Karachi: Karachi population to hit 27.5 million in 2020. July 10, 2007. http://www.dawn.com/news/255587/karachi-karachi-population-to-hit-27-5-million-in-2020

${ }^{14}$ Master Plan group. Op. cit.
} 


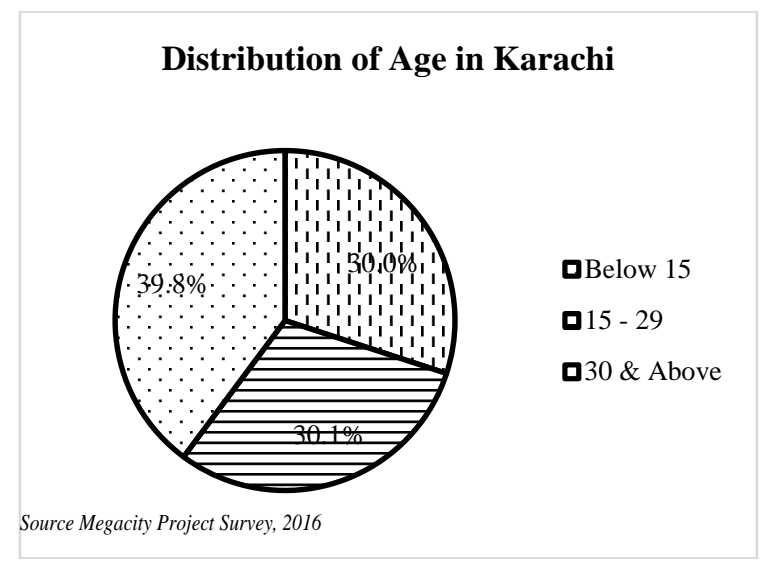

Figure 3

Youth emigration is becoming a major challenge in Pakistan and, Karachi. The Karachi megacity survey suggests that more than $48.7 \%$ of the youth living in Karachi want to migrate out (see Figure 4). Lack of adequate facilities for young people helps to motivate them to migrate abroad. The migration data of 2014- 2015 show a $20.8 \%$ outmigration increase ${ }^{15}$. Overall, young people in Pakistan are feeling insecure and are not able to find good opportunities for building their future ${ }^{16}$, this is partly because of corruption, lack of trust of law enforcement agencies, joblessness, economic problems, lack of social support and lack of career opportunities. For the past six years more than 0.22 million people migrated abroad from Karachi for employment, which is the highest percentage of any of the larger cities of Pakistan ${ }^{17}$.

\footnotetext{
${ }^{15}$ Saleem, Khilji, About one million Pakistanis migrated abroad for jobs during 2015. March 31, 2016. http://dunyanews.tv/en/SpecialReport/320657-About-one-million-Pakistanis-migrated-abroad-for-j.

${ }^{16}$ David, Steven, Next Generation Insecure Live, Untold stories. British Council Pakistan, 2014.

${ }^{17}$ Bureau of Emigration \& Overseas Employment Government of Pakistan, Op. cit.
} 


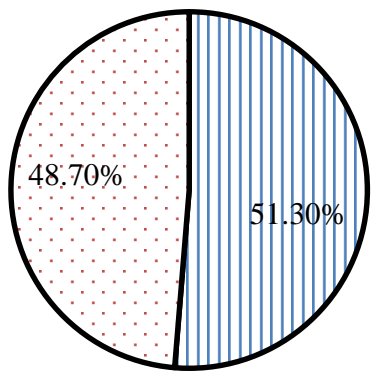

QWant to remain in Karachi

口Want to leave Karachi

Source Megacity Project Survey, 2016

Figure 4

Study analyzes the education level of youth wants to leave Karachi and reveals the higher the people qualified the higher they want to leave Eighty-eight percent of the youth attended school. Of these $49.4 \%$ want to migrate out (see Distribution of Youth wants to migrate (Table-1). Further, 29.9\% with education at the middle and lower levels want to migrate out and $47.7 \%$ having secondary and higher, and $22.4 \%$ having university degrees from the youth cohort that want to migrate out (see Figure 5). Youth that want to migrate out are from diverse backgrounds. It is surprising that unemployment is not the only factor motivating out-migration among the youth of Karachi.

\section{Distribution of Youth wants to migrate (Table-1)}

\begin{tabular}{|l|c|c|}
\hline Attended School & Youth & Youth want to leave \\
\hline Never Attended & $11.3 \%$ & $43.7 \%$ \\
\hline Ever Attended & $88.7 \%$ & $49.4 \%$ \\
\hline
\end{tabular}

Source Megacity Project Survey, 2016

There are several factors that are strongly related to the emigration of youth. According to the Karachi Mega City Survey, 24.1\% of youth respondents are full-time employed, of which, $63.5 \%$ want to migrate out, $1.9 \%$ are part- time employed, out of which $34 \%$ want to migrate out, $27.3 \%$ are housewives, of which $59.8 \%$ want to migrate out, only $4.3 \%$ are unemployed and looking for work, of which $76.1 \%$ want to migrate out, $35.2 \%$ are students, of which $57.3 \%$ want to leave Karachi and $3.9 \%$ were self-employed, of which, $75.5 \%$ want to migrate out. (See

Status of Youth wants to leave Karachi (Table-2). 
Status of Youth wants to leave Karachi (Table-2)

\begin{tabular}{|l|c|c|c|}
\hline Activities of Youth & Youth\% & $\begin{array}{c}\text { Want } \\
\text { to leave }\end{array}$ & $\begin{array}{c}\text { Remain } \\
\text { in } \\
\text { Karachi }\end{array}$ \\
\hline Full-time Employed & $24.1 \%$ & $63.5 \%$ & $36.5 \%$ \\
\hline Part-time Employed & $1.9 \%$ & $34 \%$ & $66 \%$ \\
\hline Housework/ Housewife & $27.3 \%$ & $59.8 \%$ & $40.2 \%$ \\
\hline Unemployed but Looking for work & $4.3 \%$ & $76.1 \%$ & $23.9 \%$ \\
\hline Unemployed but not looking for work & $1.6 \%$ & $56.1 \%$ & $43.9 \%$ \\
\hline Don't work & $1.7 \%$ & $62.5 \%$ & $37.5 \%$ \\
\hline Student & $35.2 \%$ & $57.3 \%$ & $42.7 \%$ \\
\hline Self-employed & $3.9 \%$ & $75.5 \%$ & $24.5 \%$ \\
\hline Total & $100.0 \%$ & & \\
\hline
\end{tabular}

Source Megacity Project Survey, 2016

Karachi city is receiving less inflow of brain skills in contrast to the drain of workers from Karachi. As noted, this situation is contributing to a serious brain drain and is having a negative impact on the City's economy. The government needs to develop new vocational training and skill enhancement centers for coping with the shortage of skilled workers. Besides the development of skill-based training centers, the government needs to prepare strategic plans for professional education that should help to motivate youth to remain and contribute to the development of the city. Study reveals the migration here and there represents a few catastrophes in the provincial just as in the urban zones even though; there are benefits resultant from it. In most country zones, the effect of provincial urban migration was a fast disintegration of the rustic economy prompting incessant neediness and nourishment weakness ${ }^{18}$.

\footnotetext{
${ }^{18}$ Babi, Moses Lomoro Alfred, Xiong Guogping, and John Leju Celestino Ladu. "Causes and consequences of rural-urban migration: The case of Juba Metropolitan, Republic of South Sudan." IOP Conference Series: Earth and Environmental Science. IOP Publishing, 2017. 1-9.
} 


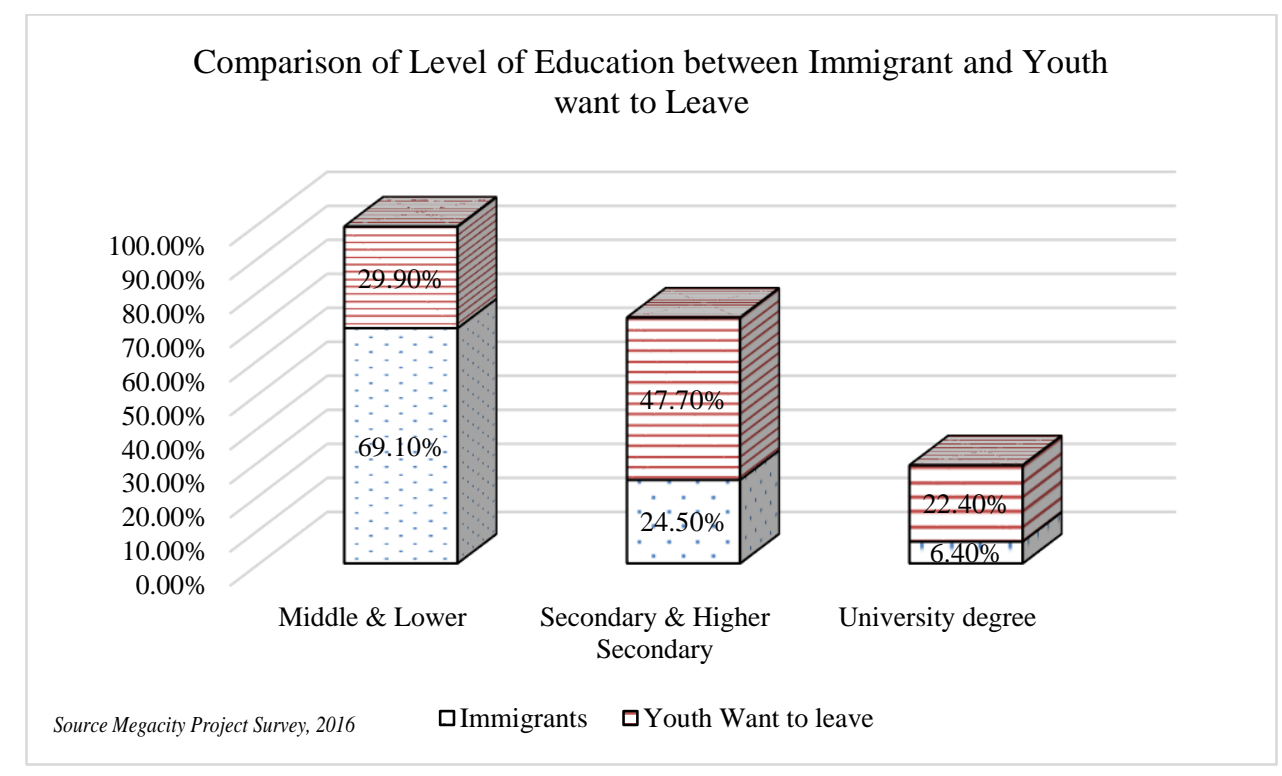

Figure 5

\section{Emigration from Pakistan}

Pakistan has witnessed outward migration for decades ${ }^{19} \mathrm{~s}$. According to the Bureau of Emigration and Overseas Employment, Government of Pakistan, more than 3.7 million people have migrated from Pakistan between 2010 to $2015^{20}$ (See Table 3and Error! Reference source not found.). Studies suggest that people who are more skilled are more likely to migrate from Pakistan ${ }^{21}$.

\section{Yearly migration from Pakistan (Table-3)}

\begin{tabular}{|c|c|}
\hline Year of Migration & Number of Emigrants (Unit) \\
\hline 2010 & 362,904 \\
\hline 2011 & 456,893 \\
\hline 2012 & 638,587 \\
\hline 2013 & 622,714 \\
\hline 2014 & 752,466 \\
\hline 2015 & 946,571 \\
\hline Total & $3,780,135$ \\
\hline
\end{tabular}

Source: Bureau of Emigration and Overseas Employment, Government of Pakistan

\footnotetext{
${ }^{19}$ Bureau of Emigration \& Overseas Employment Government of Pakistan, Op. cit.

${ }^{20}$ Ibid.

${ }^{21}$ Talal. Its Time to Stop The Brain Drain from Pakistan. 2015. https://propakistani.pk/2015/09/04/its-time-tostop-the-brain-drain-from-pakistan/.
} 


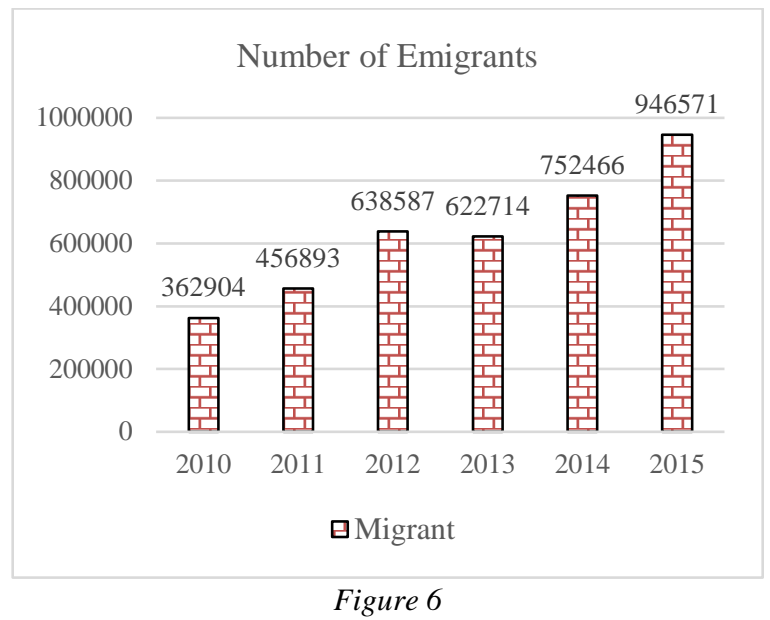

\section{Youth Migration Globally}

Migration is becoming a global challenge. Currently 73.8 million young people globally are seeking employment and millions are searching for better employment ${ }^{22}$. The youth cohort is defined as all people in the population having ages $15-29$ years $^{23}$. According to various studies, $30 \%$ of the world's population is comprised of youth ${ }^{24}$. Further, in a world of 7.2 billion people 232 million people are international migrants, of which, $10 \%$ are youth ${ }^{25}$.

Young people migrate due to many motivational factors such as cultural understanding, search for better employment, economic crisis. Lack of education facilities, unstable socio-political conditions, poverty and unemployment are the main causes of youth migration ${ }^{26}$. A gathering of people migrate dependent on the current conditions and the intentions in it contrasts starting with one individual then onto the next relying upon the conditions that realized the choice to migrate. Migration is a specific procedure influencing people or families/family units with certain economic, social, educational and segment qualities. The movement of individuals from rustic to urban zones is a typical scene in South Sudan ${ }^{27}$. Young people from Japan are migrating to United States and Europe for cultural exchange ${ }^{28}$. In India, 1.25 million people emigrated to USA, UK and Canada during the period of 1950 to 2000. Today 3 million people have

\footnotetext{
${ }^{22}$ International Labour office, Global Employment Trend 2013. Geneva: International Labour Office, 2013.

${ }^{23}$ UNDP, Jawan Pakistan Youth to Youth Conversion Guidelines. 2015. http://nhdr.undp.org.pk/wpcontent/uploads/2015/05/Raza-Kar-Youth-to-Youth-Conversation-Guidelines.pdf.

${ }^{24}$ Mercy Corps and IOM. Eduardo Aguirre Davila, Individual, Family, Social, Community and Institutional Characteristics Associated With the De-linkage and Reintegration of Adolescents and Young Women who Have Belonged to Illegal Armed Groups. Washington D.C: International Organization of Migration, 2013.

${ }^{25}$ International Labour Organization. Youth and Migration (Labour Migration). 2016.

http://www.ilo.org/global/topics/labour-migration/policy-areas/youth-and-migration/lang--en/index.htm.

${ }^{26}$ Olga, Ranceva, "Youth Unemployment and Emigration Trends." Intelectual Economics, 2014: Vol. 8, No. 1(19), p. 165-177.

${ }^{27}$ Babi, Guogping and Ladu 2017,Op.cit.

${ }^{28}$ Yuiko, Fujita, Cultural Migration from Japan. Lexington Books, 2009.
} 
migrated to Middle East from India ${ }^{29}$. Many countries like China and Bosnia \& Herzegovina have established centers for counseling and training of young migrants ${ }^{30}$. Nigeria took the initiative for enhancing the skills of youth through vocational training and $90 \%$ of the youth cohort there has employment ${ }^{31}$. Causes of migration in Eastern and Central Africa are instability, poor economic situation, regional conflicts and poverty among youth ${ }^{32}$. Studies reveals that ratio of the movements of foreigners entering the EU is evolving. While in certain years movement has been essentially determined by monetary thought processes and family reunification, over the most recent couple of years Europe has encountered a mind-boggling wave of exiles escaping wars furthermore, clashes in Syria, Afghanistan, Iraq and different nations ${ }^{33}$. In both 2015 and 2016, about 1.2 million first-time refuge applications were enrolled in the $\mathrm{EU}^{34}$. Study reveals survey of Somaliland and Puntland depicted unemployment is the significant driver of migration of youth proportion Mogadishu 21\%, Burco 20\% and Bossaso $18 \%$ were the most noteworthy contrasted with Galkayo 13\%, Baydhabo $13 \%$, Kismayo $8 \%$ and Beledweyne $7 \%$. The study findings can be extrapolated to show that the significant driver of movement in Somaliland and Puntland, which have relative harmony contrasted with southern locales and Mogadishu, is the absence of accessible openings for work for youth. Moreover, a considerable lot of the vagrants are from poor families, and they move with the point of helping those abandoned. Because of living difficult life, a few guardians think migration is financially useful for the family. In view of the unavoidable unemployment and financial challenges, one center gathering member contended that youth want to kick the bucket in the oceans or deserts attempting to arrive at Europe as opposed to sitting at home and sitting idle. Also, a few families are not ready to pay the school education costs of their kids. In this way, numerous young emphatically accept that relocation is the approach to enable their families to defeat financial challenges. Youth in Galkayo needed to support their family so they are moving ${ }^{35}$.

Migration of youth for improved education, employment and for marriage is a highly important move in their life. Migration also opens new opportunities for youth in terms of new work possibilities, building self-confidence, paving the way for higher education, and enabling them to learn skills that increase their competencies and demand in the job

${ }^{29}$ Ravi Srivastava, S.K. Sasikumar. "An Overview of migration in India, Its impact and Key issues." Migration Development Pro Poor Policy Choices in Asia. Dhaka, 2003.

${ }^{30} \mathrm{UN}$. Youth and Migration. 11 15, 2013. http://www.un.org/esa/socdev/documents/youth/fact-sheets/youthmigration.pdf.

${ }^{31}$ Jeronimo Cortina, Patrick Taran, Alison Raphael. Youth and Migration: Challenges and Opportunities.

Geneva: Graduate Institute of International and Developmental Studies, 2014.

${ }^{32}$ Ibid.

${ }^{33}$ Elisabeth Jeans, Wood, Insurgent Collective Action and Civil War in El Salvador. UK: Cambridge

Univeristy Press, 2003.

${ }^{34}$ Batsaikhan, Uuriintuya, Zsolt Darvas, and Inês Gonçalves Raposo. People on the move: migration and mobility in the European Union. Brussels: Bruegel, 2018

${ }^{35}$ Wasuge, Mahad. Youth migration in Somalia; Causes, Consequences and Possible Remedies. Mogadishu: Heritage Institute for Policy Studies, 2018. 
market ${ }^{36}$. International migration helps young people to build their international profession network that will enable them find better employment opportunities ${ }^{37}$.

\section{Methodology}

The study based on primary and secondary data. The primary data collected through Karachi Megacity Survey. The city was divided into its six districts and six cantonment areas. All districts were further divided into a total of 18 towns. Each district was subdivided into a different number of towns based on population density and six cantonments. In Each town and cantonment, blocks were defined on basis of the total number of households in that block Overall 13,233 blocks were identified by the Census Commission of Pakistan for Karachi. The average number of households in each block was 225. Two-staged stratified sampling was used to draw the sample. At the first stage, $1 \%$ block from each town and cantonment were selected through systematic random sampling after a random starting point. At the second stage, 15 households were selected for a visit through systematic random sampling after a random starting point. In total, 1991 households were visited for the survey and a total of 11,127 respondents were interviewed during Karachi Megacity Survey out of which 3,340 (30\%) belonged to the youth cohort ${ }^{38}$. The secondary collected through a review of the literature published in research articles, magazines, books and reports ${ }^{39}$. The research focused on determining the intensity of factors that are triggering youth to migrate from Karachi, Pakistan. The study used logistic regression analysis via SPSS to predict the impact of independent variables on the dependent variable.

${ }^{36}$ Aroosa. Shaukat, Youth deriven out by lack of jobs. November 24, 2011.

http://tribune.com.pk/story/296439/population-research-conference-poverty-unemployment-pushing-youthout-of-pakistan-researchers/.

${ }^{37}$ UNDESA. International Migration in a Globalizing world: The Role of Youth. 2011.

http://www.un.org/esa/population/publications/technicalpapers/TP2011-1.pdf.

38 Jameel, Kiran, and Ammad Zafar. Emerging Health Issues in Megacities: An Analysis on Causes of NonCommunicable Diseases in Karachi. Public Policy and Administration Research, Vol 6, No. 11. (2016).

${ }^{39}$ Mustafa, Sadaf, M. Sadiq Ali Khan, and Ammad Zafar. "Role Of Women In Development Of Pakistan: A Case Study of Women Participation in Labour Force in Pakistan." Pakistan Journal of Gender Studies. Vol 13, No. 1 (2016). 


\section{Research variables}

The research reported here seeks to identify and examine the factors that are motivating youth emigration from Karachi. Logistic regression analysis is used to examine the relationships between youth emigration and hypothetical factors that may be motivating it (See Table 5).

Details of dependent and Independent variables

\begin{tabular}{|l|l|}
\hline $\begin{array}{l}\text { Dependent } \\
\text { (DV) / } \\
\text { Independent } \\
\text { variables (IV) }\end{array}$ & \multicolumn{1}{|c|}{ Definition } \\
\hline $\begin{array}{l}\text { Want to leave } \\
\text { Karachi (DV) }\end{array}$ & $\begin{array}{l}\text { People who want to leave Karachi for different purposes, } \\
\text { immediately or in the next five years }\end{array}$ \\
\hline Insecurity (IV) & $\begin{array}{l}\text { People feel insecure because of law and order, and security } \\
\text { conditions in Karachi }\end{array}$ \\
\hline $\begin{array}{l}\text { Middle \& lower } \\
\text { education (IV) }\end{array}$ & People having education below matric or eight grades \\
\hline $\begin{array}{l}\text { Secondary or } \\
\text { higher } \\
\text { secondary } \\
\text { education (IV) }\end{array}$ & $\begin{array}{l}\text { People having completed a matric Grade 10 or completed a higher } \\
\text { secondary school certificate/intermediate level Grade 12. }\end{array}$ \\
\hline $\begin{array}{l}\text { Unemployment } \\
\text { (IV) }\end{array}$ & Unemployed people having age above 15 years and looking for job \\
\hline $\begin{array}{l}\text { Self - employed } \\
\text { (IV) }\end{array}$ & People who are conducting their own business \\
\hline $\begin{array}{l}\text { Lack of } \\
\text { opportunity } \\
\text { (IV) }\end{array}$ & $\begin{array}{l}\text { Not getting a job and/or a chance of promotion in their respective } \\
\text { field of specialization }\end{array}$ \\
\hline $\begin{array}{l}\text { Lack of social } \\
\text { support (IV) }\end{array}$ & $\begin{array}{l}\text { Not getting any financial and non-financial support for career } \\
\text { development from their society and/or family. }\end{array}$ \\
\hline $\begin{array}{l}\text { Economic } \\
\text { problems (IV) }\end{array}$ & Insufficient resources to satisfy needs of youth \\
\hline Urdu (IV) & People with Urdu as mother-tongue \\
\hline
\end{tabular}

\section{Analysis and Interpretation}

\section{Logistic Regression}

Logistic regression is appropriate for the analyses of dichotomous data. Logistic regression has three assumptions: The outcome must be discreet and variables should be dichotomous. Data should not have any outliers. Predicator variables do not have multi- 
collinearity among variables. The study assumed that the predictor variables are not inter-correlated the model ${ }^{40}$.

Logistic regression analyzes the impact of independent variables on a dependent variable (See Table 4 and Table 5). All the variables are recoded into binary digits $(0,1)$ e.g. $0=$ no economic problems and $1=$ economic problems. Through this analysis, significant factors are identified which appear to be motivating Karachi youth emigration.

\begin{tabular}{|l|l|l|l|}
\hline \multicolumn{4}{|c|}{ Model Summary of logistic regression analysis of dependent and independent } \\
variables (Table 4)
\end{tabular}

$\mathrm{R}^{2}$ shows the variability in the dependent variable as influenced by the independent variables. The higher value of $\mathrm{R}^{2}$ the higher the variability explained by the model and the better the model fit to the data ${ }^{41}$. In this research the $\mathrm{R}$ Square value shows that the independent variables explain $35.9 \%$ variability that means other factors are affecting dependent variable e.g. environment threats, lack of water, climate change, cultural diversification and political conditions in the country etc. ${ }^{42}$.

\section{Logistic regression analysis of dependent and independent variables (Table 5)}

\begin{tabular}{|c|c|c|c|}
\hline Step $1^{\text {a }}$ Variables in Equation & df & Sig. level & $\operatorname{Exp}(B)$ \\
\hline Insecurity (1) & 1 & 0.000 & 3.70 \\
\hline Unemployment (1) & 1 & 0.000 & 3.67 \\
\hline Secondary \& higher Edu. (1) & 1 & 0.000 & 3.18 \\
\hline Middle \& lower Edu. (1) & 1 & 0.001 & 2.93 \\
\hline Economic problems (1) & 1 & 0.000 & 2.60 \\
\hline Lack of opportunities (1) & 1 & 0.000 & 2.42 \\
\hline Self-employed (1) & 1 & 0.002 & 2.03 \\
\hline Urdu (1) & 1 & 0.000 & 1.60 \\
\hline Lack of social support (1) & 1 & 0.000 & 0.32 \\
\hline Constant & 1 & 0.000 & 0.01 \\
\hline
\end{tabular}

\footnotetext{
${ }^{40}$ Statistics Solutions. What is logistic regression? 2016. http://www.statisticssolutions.com/what-is-logisticregression/.

${ }^{41}$ Institute for digital research education. What is pseudo R-squared? 2016.

http://www.ats.ucla.edu/stat/mult_pkg/faq/general/Psuedo_RSquareds.htm (accessed 2016).

${ }^{42}$ APHG Class wiki. Migration Push/Pull Factors. September 1, 2016.

http://lewishistoricalsociety.com/wiki2011/tiki-read_article.php?articleId=28 (accessed September 2016, 3).
} 
The analysis shows that unemployment is still one of the major significant factors stimulating Karachi youth emigration. Unemployment has a significant impact of 3.67 times on emigration for each unit increase in unemployment. When people feel insecure they tend to relocate or try to relocate. Insecurity evidences an impact of 3.74 times on youth emigration. The impact of secondary and higher education is 3.18 times and the impact of middle \& lower education is 2.93 times. Youth with secondary \& higher education thus are more likely to migrate compared to those youth having less education. Ethnicity also has a significant impact on youth emigration. Study reveals youth who belong to a major ethnic group (the Urdu specking community) are more likely to migrate than other ethnic groups. It has impact of 1.60 times with a unit increase in youth emigration. Self-employment of youth has an impact of 2.03 times on emigration. Lack of opportunities are triggering young people's emigration and are having a significant impact of 2.42 times on emigration. Lack of Social Support has an impact of 0.321 times on youth emigration. It may be concluded that youth who are receiving support from the society are less likely to emigrate. Economic problems are triggering the mindset of youth toward emigration; this variable has a 2.6 impact. According to the analysis, people who are facing economic problems are more likely to migrate.

\section{Conclusion}

Study reveals unemployment, lack of resources, financial crisis, economic crisis and unstable socio-political conditions are global factors which are motivating youth for migration. The analysis of the Karachi Megacity Survey data identified that people who were feeling insecure due to prevailing crime in the city, people having skills and remaining jobless and those failing to find better opportunities for their career were more likely to want to emigrate.

\section{Policy Recommendation}

- Government should prepare policies that strengthen entrepreneur's confidence that they will benefit from staying in Pakistan.

- Government should promote new entrepreneurs to create more job opportunities.

- Government should provide better opportunities to young doctors and teachers to meet the job market demand in the health and education sectors.

- Government should commence new businesses on basis of Public Private Partnerships to create more opportunities for young people.

- Government should promote development of a stronger research culture according to international standards to find solution for social, political and economic problems 


\section{Bibliography}

APHG Class wiki . Migration Push/Pull Factors. September 1, 2016. http://lewishistoricalsociety.com/wiki2011/tiki-read_article.php?articleId=28 (accessed September 2016, 3).

Babi, Moses Lomoro Alfred, Xiong Guogping, and John Leju Celestino Ladu. "Causes and consequences of rural-urban migration: The case of Juba Metropolitan, Republic of South Sudan." IOP Conference Series: Earth and Environmental Science. IOP Publishing, 2017. 1-9.

Batsaikhan, Uuriintuya, Zsolt Darvas, and Inês Gonçalves Raposo. People on the move: migration and mobility in the European Union. Brussels: Bruegel, 2018.

Bureau of Emigration \& Overseas Employment Government of Pakistan. Occupational Wise 2016. 2016. http://www.beoe.gov.pk/files/statistics/occupational-wise-2016.pdf.

Demographia. Demogrphia World Urban Areas 12th Annual Edition. April 2016. http://www.demographia.com/db-worldua.pdf.

EbaseZone. Chain Base Method. 2016. http://www.emathzone.com/tutorials/basicstatistics/chain-base-method.html.

Fujita, Yuiko. Cultural Migration from Japan. Lexington Books, 2009.

Hamdani, S.A.R. Bureau of emigration and overseas employment: Performance and evaluation. Bureau of Emigration and overseas Employment, 2006.

Institute for digital research education. What are pseudo R-squareds? 2016. http://www.ats.ucla.edu/stat/mult_pkg/faq/general/Psuedo_RSquareds.htm (accessed 2016).

Internation Labour Organization. Youth and Migration (Labour Migration). 2016. http://www.ilo.org/global/topics/labour-migration/policy-areas/youth-andmigration/lang--en/index.htm.

Jameel, Kiran, and Ammad Zafar. Emerging Health Issues in Megacities: An Analysis on Causes of Non-Communicable Diseases in Karachi. Public Policy and Administration Research, 2016. Vol 6, No. 11. 20-26

Jeronimo Cortina, Patrick Taran, Alison Raphael. Youth and Migration: Challenges and Opportunties. Geneva: Graduate Institue of International and Developemntal Studdies, 2014. 
Khilji, Saleem. About one million Pakistanis migrated abroad for jobs during 2015. March 31, 2016. http://dunyanews.tv/en/SpecialReport/320657-About-one-millionPakistanis-migrated-abroad-for-j.

Master Plan group of Offices City District Government Karachi in Association with M/sEngineering consultant (Pvt.) Ltd. Karachi Strategic Development Plan 2020. Karachi: Master Plan group of Offices City District Government Karachi, 2007.

Mercy Corps and IOM. Eduardo Aguirre Davila, Individual, Family, Social, Community and Institutional Characteristics Associated With the De-linkage and Reintegration of Adolescents and Young Women who Have Belonged to Illegal Armed Groups. Washington D.C: International Organization of Migration, 2013.

Mustafa, Sadaf, M. Sadiq Ali Khan, and Ammad Zafar. Role Of Women In Development Of Pakistan: A Case Study of Women Participation in Labour Force in Pakistan. Pakistan Journal of Gender Studies 13, no. 1 (2016): 221-234.

Office, Internation Labour. Global Employment Tren 2013. Geneva: International Labour Office, 2013.

Ranceva, Olga. "Youth Unemployment and Emigration Trends." Intellectual Economics, 2014: Vol. 8, No. 1(19), 165-177.

Ravi Srivastava, S.K. Sasikumar. "An Overview of migration in India, Its impact and Key issues." Migration Development Pro Poor Policy Choices in Asia. Dhaka, 2003.

Sharif, Aziz ullha. Karachi: Karachi population to hit 27.5 million in 2020. July 10, 2007. http://www.dawn.com/news/255587/karachi-karachi-population-to-hit-27-5million-in-2020.

Shaukat, Aroosa. Youth deriven out by lack of jobs. November 24, 2011. http://tribune.com.pk/story/296439/population-research-conference-povertyunemployment-pushing-youth-out-of-pakistan-researchers/.

Statistics Solutions. What is logistic regression. 2016.

http://www.statisticssolutions.com/what-is-logistic-regression/.

Steven, David. Next generation insecure live, untold stories. British Council Pakistan, 2014.

Talal. Its Time to Stop The Brain Drain from Pakistan. 2015. https://propakistani.pk/2015/09/04/its-time-to-stop-the-brain-drain-from-pakistan/. 
Talal, Syed. it's Time to Stop the Brain Drain from Pakistan. September 4, 2015. https://propakistani.pk/2015/09/04/its-time-to-stop-the-brain-drain-from-pakistan/.

Times, Newyork. Survey of Pakistan's Young Predicts 'Disaster' if Their Needs Aren't Addressed. November 22, 2009.

http://www.nytimes.com/2009/11/22/world/asia/22pstan.html.

UN Administrtor2. The impact of Youth Migration. December 30, 2013.

http://www.unworldyouthreport.org/index.php?option=com_k2\&view=item\&layout=ite $\mathrm{m} \& \mathrm{id}=85 \&$ Itemid $=226$.

UN. Youth and Migration. 11 15, 2013.

http://www.un.org/esa/socdev/documents/youth/fact-sheets/youth-migration.pdf.

UNDESA. International Migration in a Globalizing world: The Role of Youth. 2011. http://www.un.org/esa/population/publications/technicalpapers/TP2011-1.pdf.

UNDP. Jawan Pakistan Youth to Youth Conversion Guidellines. 2015.

http://nhdr.undp.org.pk/wp-content/uploads/2015/05/Raza-Kar-Youth-to-YouthConversation-Guidelines.pdf.

UNDP. Youth Employment and Social Cohesion. January 2015.

http://www.pk.undp.org/content/pakistan/en/home/operations/projects/crisis_prevention _and_recovery/youth-employment-and-social-cohesion.html.

United Nation. World Youth Report. NNew York: United Nation, 2013.

Wasuge, Mahad. Youth migration in Somalia; Causes, Consequences and Possible Remedies. Mogadishu: Heritage Institute for Policy Studies, 2018.

Wood, Elisabeth Jeans. Insurgent Collective Action and Civil War in El Salvador. UK: Cambridge Univeristy Press , 2003. 